\title{
Glycerin levels while maintaining the electrolyte balance in finishing pig diets
}

\author{
Rafaeli Gonçalves Leite ${ }^{1}$, Anderson Corassa ${ }^{1 *}$, Ana Paula Silva Ton ${ }^{1}$, Claudia Marie Komiyama1, \\ Alessandro Borges Amorim², Charles Kiefer ${ }^{3}$
}

\author{
${ }^{1}$ Universidade Federal de Mato Grosso, Instituto de Ciências Agrárias e Ambientais, Sinop, MT, Brazil. \\ ${ }^{2}$ Universidade Federal de Mato Grosso, Instituto de Ciências Agrárias e Tecnológicas, Rondonópolis, MT, Brazil. \\ ${ }^{3}$ Universidade Federal de Mato Grosso do Sul, Faculdade de Medicina Veterinária e Zootecnia, Campo Grande, MS, Brazil.
}

\begin{abstract}
The objective of this study was to evaluate performance and carcass and meat characteristics of finishing pigs fed diets with different levels of glycerin, while maintaining the electrolyte balance. Forty barrows with an initial weight of $97.76 \pm 13.44 \mathrm{~kg}$ were distributed, in a randomized block design, into four treatments with five replicates. Treatments consisted of diets containing $0,5,10$, and $15 \%$ glycerin. Inclusions of salt and sodium bicarbonate were adjusted to balance the sodium content and maintain the same electrolyte balance of the diets as a function of glycerin inclusions. In vivo backfat thickness, daily feed intake, daily weight gain, and feed conversion were measured. After the animals were slaughtered, $\mathrm{pH}$ and temperature were measured $45 \mathrm{~min}$ and $24 \mathrm{~h}$ postmortem, and backfat thickness, loin-eye area, drip loss, and colorimetry were determined. Glycerin inclusion levels did not influence the performance of barrows. Hot carcass weight, dressing percentage, and lightness had higher values when pigs were fed diets containing 2.32, 2.43, and $2.61 \%$ glycerin, respectively. The other carcass and meat characteristics were not influenced. Glycerin can be used in finishing pig diets without compromising results of performance or carcass and meat characteristics up to the inclusion level of $15 \%$.
\end{abstract}

Key Words: biodiesel, byproduct, carcass quality, glycerol, meat quality

\section{Introduction}

The search for alternative fuels that can be used together with the diesel from petroleum has paved the way for the expansion of biodiesel production. Biodiesel has the great advantage of being produced from renewable sources, such as oilseeds, mirrored by the enormous growth of its production and consequent supply of the byproduct glycerin, which was $69 \mathrm{~m}^{3}$ in 2005 and rose to $3,419,838 \mathrm{~m}^{3}$ in 2014 (ANP, 2015).

The main component of glycerin, glycerol, is a highenergy compound present in feedstuffs and in the animal metabolism that has the potential to be used as a partial substitute for cereal grains or other high-starch ingredients in pig diets (Berenchtein et al., 2010; Gallego et al., 2014;

Received: July 7, 2016

Accepted: November 29, 2016

*Corresponding author: anderson_corassa@ufmt.br

http://dx.doi.org/10.1590/S1806-92902017000300005

How to cite: Leite, R. G.; Corassa, A.; Ton, A. P. S.; Komiyama, C. M.; Amorim, A. B. and Kiefer, C. 2017. Glycerin levels while maintaining the electrolyte balance in finishing pig diets. Revista Brasileira de Zootecnia 46(3):211-217.

Copyright (c) 2017 Sociedade Brasileira de Zootecnia. This is an Open Access article distributed under the terms of the Creative Commons Attribution License (http://creativecommons.org/licenses/by/4.0/), which permits unrestricted use, distribution, and reproduction in any medium, provided the original work is properly cited.
Gomide et al., 2012); however, a consensus has not been reached as to its inclusion level in diets. Berenchtein et al. (2010) reported that purified glycerin can be used at levels up to $9 \%$ in the diet, whereas Huepa et al. (2015) asserted it is possible to include up to $12 \%$ without impairing the performance of finishing animals. Variations in animalperformance responses are related to residues from the biodiesel production process that affect the composition of glycerin, especially sodium, which changes the electrolyte balance of diets. High levels of this mineral can cause thirst, increased water intake, and an expansion in cell volume, reducing feed intake (Brêtas et al., 2011). Oliveira et al. (2013) analyzed glycerin samples from Brazilian mills and recorded sodium levels ranging from 0.61 to $2.82 \%$. Thus, we hypothesize that including glycerin for finishing pigs, performing adaptation of the electrolyte balance of diets, would not change performance and meat and carcass characteristics.

Glycerol can be used in lipogenesis and gluconeogenesis, contributing to increase the meat lipid contents, reducing the catalysis of amino acids, and increasing the accumulation of protein in the muscle (Lin, 1977), in addition to the possibility of changing the meat quality parameters depending on the level of inclusion in the diet of pigs in the finishing stage. Gomide et al. (2012) observed a linear increase in backfat 
thickness and a linear decrease in thawing loss and shear force as the glycerin level in the diets was increased. Mendoza et al. (2010), however, did not observe any effect of glycerin inclusion on quantitative and qualitative characteristics of pork.

It is thus necessary to determine the ideal level of glycerin in the feeding of finishing pigs that does not compromise their performance or carcass and meat characteristics by correcting the electrolyte balance of the diet. In view of these considerations, the objective of this study was to evaluate the effect of glycerin levels in diets for finishing pigs on their performance and carcass and meat characteristics, while maintaining the electrolyte balance.

\section{Material and Methods}

The experiment was conducted in June 2015, in Santa Carmem, MT, Brazil, complying with the ethical principles of animal experimentation adopted by the National Council for Animal Experimentation Control and approved by the local Ethics Committee in Animal Use (case no. 23108.700673/14-4).

Forty castrated male crossbred pigs of a commercial line, with an initial weight of $97.76 \pm 13.44 \mathrm{~kg}$, were distributed, in randomized block design, into four treatments with five replications with two animals per experimental unit. The initial weight of the pigs was used as a criterion for the composition of the blocks. Animals were housed in 20 stalls of a masonry shed covered with fibrocement tiles. Stalls were equipped with feeders in the front and nipple drinkers in the distal part.

Treatments (Table 1) were composed of corn and soybean meal-based diets with inclusion of glycerin at the levels of 5,10 , and $15 \%$, formulated to meet the requirements of the category, following recommendations of Rostagno et al. (2011).

The electrolyte balance of the diet was calculated as $\mathrm{Na}^{+}+\mathrm{K}^{+}-\mathrm{Cl}^{-}(\mathrm{mEq} / \mathrm{kg})$ and adjusted to $250 \mathrm{mEq} / \mathrm{kg}$ for all glycerin inclusions through different inclusions of salt $(\mathrm{NaCl})$ and sodium bicarbonate $\left(\mathrm{NaHCO}_{3}\right)$. The glycerin used was obtained from biodiesel production, having soy oil as raw material (Table 2), and contained 3,280 kcal $/ \mathrm{kg}$ metabolizable energy (Verussa, 2015).

Feed and water were supplied ad libitum during the entire experimental period. Stalls were cleaned daily by scraping off the wastes and weekly washing. The experimental period lasted 21 days, divided into two periods: the first lasted 14 days and the second seven days. Animals were weighed at the beginning and end of each period, and their in vivo backfat thickness was measured by ultrasonography using a backfat measuring device (Microem, Ribeirão Preto, SP, Brazil), near the last rib and $5 \mathrm{~cm}$ from the right and left side of the midline, with the animal standing in a natural position; the final average value of both observations was considered. Daily feed intake (DFI), daily weight gain (DWG), and feed conversion of each experimental unit were evaluated.

At the end of the performance period, all animals were identified by a tattoo and then fasted (for solids only) for $12 \mathrm{~h}$ to be transported to the slaughterhouse, where they were stunned, slaughtered, trimmed, and eviscerated according to procedures established by the slaughterhouse,

Table 1 - Centesimal and calculated composition of the diets

\begin{tabular}{|c|c|c|c|c|}
\hline \multirow{2}{*}{ Ingredient $(\mathrm{g} / \mathrm{kg})$} & \multicolumn{4}{|c|}{ Crude glycerin level in the diets $(\%)$} \\
\hline & 0 & 5 & 10 & 15 \\
\hline Corn & 565.9 & 513.8 & 463.4 & 401.8 \\
\hline Soybean meal & 102.7 & 107.5 & 108.5 & 120.0 \\
\hline DDGS & 300.0 & 300.0 & 300.0 & 300.0 \\
\hline Glycerin & 0 & 50.0 & 100.0 & 150.0 \\
\hline Dicalcium phosphate & 9.0 & 9.5 & 9.6 & 10.0 \\
\hline Calcitic limestone & 4.4 & 4.1 & 4.0 & 3.9 \\
\hline Common salt & 4.0 & 0.9 & 0 & 0 \\
\hline L-lysine & 3.4 & 3.4 & 3.4 & 3.2 \\
\hline Mineral-vitamin $\operatorname{mix}^{1}$ & 2.0 & 2.0 & 2.0 & 2.0 \\
\hline DL-methionine & 0 & 0.1 & 0.3 & 0.5 \\
\hline Sodium bicarbonate & 8.6 & 8.7 & 8.8 & 8.6 \\
\hline \multicolumn{5}{|l|}{ Calculated composition } \\
\hline Metabolizable energy (kcal/kg) & 3,300 & 3,300 & 3,300 & 3,300 \\
\hline Crude protein & 179.9 & 178.1 & 174.5 & 175.0 \\
\hline Calcium & 4.4 & 4.4 & 4.4 & 4.4 \\
\hline Available phosphorus & 2.8 & 2.8 & 2.8 & 2.8 \\
\hline Sodium & 4.1 & 4.1 & 5.0 & 6.1 \\
\hline Chlorine & 3.4 & 3.4 & 4.6 & 6.3 \\
\hline Digestible lysine & 7.0 & 7.0 & 7.0 & 7.0 \\
\hline Digestible methionine & 3.0 & 3.0 & 3.0 & 3.0 \\
\hline Digestible met + cys & 5.4 & 5.4 & 5.4 & 5.4 \\
\hline Fat & 41.8 & 40.0 & 38.1 & 36.1 \\
\hline Crude fiber & 15.2 & 14.6 & 13.8 & 13.3 \\
\hline $\mathrm{EB}=\mathrm{Na}+\mathrm{K}-\mathrm{Cl}(\mathrm{mEq} / \mathrm{kg})$ & 250 & 250 & 250 & 250 \\
\hline
\end{tabular}

DDGS - dried distillers grains with solubles; EB - electrolyte balance.

${ }^{1}$ Composition of supplement per kg of product: vitamin A, 2,750,000 IU; vitamin B, $400 \mathrm{mg}$; vitamin B2, $250 \mathrm{mg}$; vitamin B6, $800 \mathrm{mg}$; vitamin B12, $900 \mathrm{mcg}$; vitamin D3, 600,000 IU; vitamin E, 15,000 mg; vitamin K3, 1,250 mg; nicotinic acid, 10,000 mg; pantothenic acid, 6,000 mg; folic acid, $125 \mathrm{mg}$; cobalt, $250 \mathrm{mg}$; copper, 5,000 mg; iron, 30,000 mg; zinc, 40,000 mg; manganese, $15,000 \mathrm{mg}$; selenium, $140 \mathrm{mg}$; iodine, $400 \mathrm{mg}$; choline, $50,000 \mathrm{mg}$; biotin, $5000 \mathrm{mcg}$; ethoxyquin, $5,000 \mathrm{mg}$; BHT, 10,000 mg; bacitracin zinc, 15,000 mg.

Table 2 - Chemical composition of glycerin

\begin{tabular}{lc}
\hline Analysis $(\mathrm{g} / \mathrm{kg})$ & Result \\
\hline Moisture & 119.9 \\
Sulfated ash & 65.7 \\
Glycerol & 785.0 \\
Methanol & 0.8 \\
Chloride & 36.5 \\
Chloride with $\mathrm{NaCl}$ & 60.0 \\
pH & 3.00 \\
\hline
\end{tabular}

Source: Technical report provided by the company Fiagril S.A. 
located $40 \mathrm{~km}$ from the experiment site. The other slaughter procedures were performed according to Normative Instruction no. 711, of November 01, 1995 (Brasil, 1995).

The $\mathrm{pH}$ and temperature measurements were taken from the Longissimus dorsi muscle between the 13th and 14th intercostal spaces, perpendicularly to the midline of the left half-carcass with an average depth of $3.5 \mathrm{~cm}$, in the periods of $45 \mathrm{~min}$ (pH45 and T45) and $24 \mathrm{~h}$ postmortem (pH24 and T24). $\mathrm{pH}$ measurements were made with a portable $\mathrm{pH}$ meter AK86 interface (model CE RS232, $\left.\mathrm{Akso}^{\circledR}\right)$, with a digital identification system, temperature compensation sensor, and appropriate glass electrode (sc18). Temperature measurements were done using a digital thermometer. In the same anatomical region, $24 \mathrm{~h}$ postmortem, the backfat thickness of the carcasses was measured with a digital caliper by inserting one end of the caliper above the hide and another in the line separating the fat layer and the meat, according to the Brazilian Carcass Classification Method (ABCS, 1973).

The loin-eye area (LEA) was evaluated from samples of the Longissimus dorsi muscle, extracted between the 12th and 13th intercostal spaces $24 \mathrm{~h}$ postmortem. The LEA of each sample was recorded on tracing paper by outlining the muscle. Drawings were scanned and opened on the AutoCAD ${ }^{\circledR}$ software. The scale was initially determined in each image and each region was outlined individually. Next, the loin-eye area measurements of each sample were obtained, following the same procedure utilized by Santos et al. (2014).

Immediately after the LEA of the carcasses was outlined, samples of approximately $100 \mathrm{~g}$ of the Longissimus dorsi muscle, extracted between 12th and 13th intercostal spaces, were collected for analyses of color and drip loss. Color evaluations were undertaken by light reflectance reading in triplicate, in three dimensions: $\mathrm{L}^{*}$ (lightness), $\mathrm{a}^{*}$ (range between green and red), and $\mathrm{b}^{*}$ (range between yellow and blue), using a colorimeter (Minolta DL65, model CR400, CIELAB system), after a standardized period of exposure to atmospheric air for $30 \mathrm{~min}$. Drip loss evaluations were based on the suspension of samples in inflated plastic bags, under the action of gravity, for a period of $48 \mathrm{~h}$ at $4{ }^{\circ} \mathrm{C}$, as described in Honikel (1998).

The experiment was conducted according to a completely randomized block design, using the initial weight of the animals for the formation of blocks. The analysis of variance was performed according to the statistical model below:

$$
\text { Yijk }=\mu+\mathrm{Gi}+\mathrm{Bj}+\varepsilon \mathrm{ijk},
$$

in which Yijk = observation of the effect of glycerin level $\mathrm{i}$ on block $\mathrm{j}$, at replication $\mathrm{k} ; \mu=$ overall mean; $\mathrm{Gi}=$ effect of glycerin inclusion levels; $\mathrm{Bj}=$ effect of blocks $\mathrm{j}$; and sijk = random error associated with each observation.

The effects related to the glycerin level were assessed by splitting the sum of squares of treatments into orthogonal contrasts to evaluate the linear, quadratic, and cubic effects. Evaluations were performed considering the 0.05 probability level for type-I error. Data were subjected to the Mixed procedure of SAS software (Statistical Analysis System, version 6) considering the 5\% probability level.

\section{Results and Discussion}

The levels of $0,5,10$, and $15 \%$ soy oil semi-purified glycerin did not influence $(\mathrm{P}>0.05)$ the variables DFI, DWG, feed conversion, body weight, and in vivo backfat thickness in any of the evaluated periods (Table 3).

The animal performance results indicated that soy oil semi-purified glycerin can be used as an alternative ingredient in finishing pig diets up to the maximum evaluated level of $15 \%$. These results are due to the attention given at the moment of formulating the diets, which allowed them to display these adjusted values, ensuring that the nutritional composition of the four diets were the closest possible; it is worth mentioning that the diets were isoenergetic and that the electrolyte balance was maintained equal for all diets. These results are in line with those found by other authors, e.g., Berenchtein et al. (2010), who studied glycerin in finishing pig diets at the levels of 3, 6 , and $9 \%$ and did not observe effects of the ingredient on animal performance, indicating the use of the ingredient up to the maximum level studied.

Similar results were found by Gallego et al. (2014), who studied neutralized semi-purified glycerin at the levels of $0,3.5,7,10.5$, and $14 \%$ and did not observe an influence on performance parameters. Gomide et al. (2012) did not observe an effect of substitution of corn in finishing pig diets for crude glycerin at the levels of $0,4,8,12$, and $16 \%$ on any of the analyzed performance traits. Similar results were reported by Berenchtein et al. (2010). Huepa et al. (2015) recommended the use of neutralized semipurified glycerin for growing pigs up to the level of $12 \%$, as they did not encounter effects that could compromise the animal performance.

However, Della Casa et al. (2009) found a negative effect on feed intake using $10 \%$ glycerin in diets for finishing pigs. The influence of glycerin on feed intake by animals is based on its sweetish taste and its sodium content, though it is known that animals tend to regulate their feed intake as a function of their sodium requirements (Bertechini, 2006). 
Different results can be observed with the use of glycerin in the diet resulting from the influence of the raw material used and the processing method. The glycerin energy value depends on its composition, especially its glycerol and fatty acid contents, which are inversely proportional and are related to its production efficiency (Kerr et al., 2009). Glycerin is a coproduct of biodiesel and then methanol, sodium, and mineral matter contents can affect the quality of the product, which has led to the establishment of a quality pattern in Brazil (Brasil, 2010). The type of glycerin may have influenced the results, because more purified sources usually have a lower energy value. Dozier et al. (2011) reported that the fatty acid content of the glycerin is positively correlated $(r=0.23)$, but the methanol and glycerol content also influence the metabolizable energy content for poultry. Glycerin derived from soybean oil, used in this study has a low level of contaminants and high level of glycerol, which allows using it as feed for finishing pig diets (Table 2). These features are common in products from more elaborate processes resulting in semi-purified glycerin.

The hot carcass weight showed a quadratic effect $(\mathrm{P}=0.0495)$ (Table 4), with its highest value $(83.36 \%)$ expressed at the glycerin level of $2.32 \%$. The dressing percentage also showed a quadratic effect $(\mathrm{P}=0.0382)$, with its highest value $(72.80 \%)$ obtained at $2.43 \%$ glycerin. Both results suggest a slight improvement in these variables as glycerin was added to the diets for finishing pigs at low levels and they may be related to the effect of glycerol on the retention of amino acids or nitrogen. According to Cerrate et al. (2006), the presence of glycerol can inhibit the activity of the phosphoenolpyruvate carboxykinase and glutamate dehydrogenase enzymes and result in a spare of the gluconeogenic amino acids, thereby benefiting the deposition of body fat.

The meat lightness had a quadratic effect $(\mathrm{P}=0.0493)$ and its highest value (57.82) was expressed at the soy oil semi-purified glycerin level of $2.61 \%$. This response is possibly related to the higher water holding capacity, given the greater protein deposition in the tissue of animals that had the inclusion of a small percentage of glycerin, influencing lightness. Mourot et al. (1994) reported that the use of glycerin improves the water holding capacity of pigs. In this regard, Egea et al. (2016), recording lower cooking losses in meat from pigs fed diets containing $10 \%$ glycerin as compared with control group, suggested that glycerin may have a certain protection effect on the muscle tissues, as it is an accessible and quick source of energy that can prevent a loss of amino acids produced by cortisol, inferred during the pre-slaughter period.

Nonetheless, the quadratic responses in hot carcass weight, dressing percentage, and $\mathrm{L}^{*}$ may reflect saturation of the metabolic pathway of the use of glycerol from the indicated levels, leading to excretion of the exceeding

Table 3 - Daily feed intake, daily weight gain, feed conversion, and in vivo backfat thickness of pigs fed diets with different glycerin levels in the finishing stage

\begin{tabular}{|c|c|c|c|c|c|c|c|c|}
\hline & \multicolumn{4}{|c|}{ Glycerin $(\%)$} & \multicolumn{3}{|c|}{ Significance level* } & \multirow{2}{*}{$\mathrm{CV}(\%)$} \\
\hline & 0 & 5 & 10 & 15 & Linear & Quadratic & Cubic & \\
\hline & \multicolumn{8}{|c|}{0 a 14 days } \\
\hline Daily feed intake $\left(\mathrm{kg} \mathrm{day}{ }^{-1}\right)$ & 3.79 & 3.75 & 3.75 & 3.77 & 0.9006 & 0.8485 & 0.9528 & 7.91 \\
\hline Daily weight gain $\left(\mathrm{g} \mathrm{day}^{-1}\right)$ & 862 & 874 & 779 & 785 & 0.1380 & 0.9558 & 0.3493 & 12.93 \\
\hline \multirow[t]{2}{*}{ Feed conversion } & 4.40 & 4.29 & 4.81 & 4.80 & 0.2481 & 0.6277 & 0.4268 & 13.58 \\
\hline & \multicolumn{8}{|c|}{15 a 21 days } \\
\hline Daily feed intake $\left(\mathrm{kg} \mathrm{day}^{-1}\right)$ & 3.35 & 3.23 & 3.32 & 3.49 & 0.7297 & 0.2200 & 0.7893 & 7.44 \\
\hline Daily weight gain $\left(\mathrm{g} \mathrm{day}^{-1}\right)$ & 684 & 700 & 702 & 697 & 0.8612 & 0.8729 & 0.9768 & 19.87 \\
\hline \multirow[t]{2}{*}{ Feed conversion } & 4.90 & 4.61 & 4.73 & 5.01 & 0.8079 & 0.7561 & 0.6914 & 26.36 \\
\hline & \multicolumn{8}{|c|}{0 a 21 days } \\
\hline Daily feed intake $\left(\mathrm{kg} \mathrm{day}^{-1}\right)$ & 3.64 & 3.58 & 3.61 & 3.68 & 0.8274 & 0.3225 & 0.5020 & 7.01 \\
\hline Daily weight gain $\left(\mathrm{g} \mathrm{day}^{-1}\right)$ & 803 & 816 & 753 & 756 & 0.1116 & 0.8488 & 0.2704 & 7.78 \\
\hline \multirow[t]{2}{*}{ Feed conversion } & 4.54 & 4.38 & 4.79 & 4.87 & 0.1700 & 0.3845 & 0.2541 & 9.88 \\
\hline & \multicolumn{8}{|c|}{ Weight (kg) } \\
\hline Day 0 & 97.14 & 97.96 & 97.77 & 97.54 & 0.9007 & 0.8416 & 0.9339 & 1.90 \\
\hline Day 14 & 109.21 & 110.19 & 108.67 & 108.53 & 0.4672 & 0.5779 & 0.3927 & 2.00 \\
\hline \multirow[t]{2}{*}{ Day 21} & 114.00 & 115.09 & 113.58 & 113.41 & 0.5333 & 0.5509 & 0.4076 & 2.01 \\
\hline & \multicolumn{8}{|c|}{ In vivo backfat thickness (mm) } \\
\hline Day 0 & 13.20 & 13.77 & 13.12 & 13.47 & 0.8678 & 0.8788 & 0.5012 & 11.90 \\
\hline Day 14 & 13.62 & 14.47 & 13.50 & 14.63 & 0.9510 & 0.8369 & 0.2254 & 10.89 \\
\hline Day 21 & 13.90 & 15.60 & 14.60 & 15.30 & 0.5535 & 0.4635 & 0.1620 & 9.94 \\
\hline
\end{tabular}

$\mathrm{CV}$ - coefficient of variation.

*Significance level $<0.05$. 
quantitative of the molecule via urine (Oliveira et al., 2014), which may result in lower energy input to the animal. Mendoza et al. (2010) reported that animals fed diets containing glycerin showed high energy concentrations in the urine.

The other carcass and meat characteristics such as backfat thickness, $\mathrm{pH}$, and temperature measured at $45 \mathrm{~min}$ and $24 \mathrm{~h}$, drip loss, $\mathrm{a}^{*}$, and $\mathrm{b}^{*}$ were not influenced $(\mathrm{P}>0.05)$ by the glycerin inclusion levels. As such, we can state that glycerin can be used in diets for finishing pigs with no harm to the carcass or meat characteristics. In the same way, Della Casa et al. (2009) did not find differences in carcass characteristics with addition of semi-purified glycerin at the levels of 0,5 , and $10 \%$. Melo et al. (2014) evaluated glycerin as an ingredient of finishing pig diets and found a significant difference for the red content, but because there was no difference in any other variables, the authors recommended the use of glycerin up to the level of $20 \%$ without influencing the meat and carcass characteristics of swine.

Evaluating simultaneously the results for LEA and backfat thickness measured in vivo and on carcass, we observed that soy oil semi-purified glycerin inclusion, even at high levels, did not influence the protein and lipid synthesis processes of the animals, possibly because all of them were in the same energy balance. Verussa et al. (2017) suggested that a reduction of circulating cholesterol and triglyceride levels could happen due to the replacement of the glycerin in corn diets, thus reducing substrate for the synthesis and transport of fatty acids by liver. However, these authors found no difference in cholesterol and plasma triglyceride in growing pigs receiving up to $15 \%$ of soy oil semi-purified glycerin. These considerations corroborate equal response between treatments in this study for in vivo backfat thickness and backfat thickness. Egea et al. (2016) and Schieck et al. (2010) also did not observe any effect on backfat thickness and LEA after providing diets with up to 10 and $8 \%$ glycerin, respectively.

Lactic acid production in the muscle during the animal slaughter, which is responsible for a $\mathrm{pH}$ decline, may increase in those fed glycerin, since glycerol can be converted to glucose in the liver and provide energy by the gluconeogenesis pathway (Lin, 1977), generating lower meat $\mathrm{pH}$ values. However, this was not observed in the present study or in the studies of Egea et al. (2016) and Linares et al. (2014).

The lack of an effect of soy oil semi-purified glycerin levels on the meat traits is related to the correction of the electrolyte balance of the diets, because when the glycerin level is elevated, sodium inclusion is also increased, leading to an increased water holding capacity of pig meat (Mourot et al., 1994). Edwards et al. (2010) emphasized the tendency of carcasses of animals that received bicarbonate to have a slower postmortem glycolysis rate, reducing the incidence of abnormal meat.

The results of the present study agree with those recorded by Berenchtein et al. (2010) and Mendoza et al. (2010), who indicated the use of purified glycerin up to $15 \%$ in pig diets without compromising the carcass characteristics of these animals. Gonçalves et al. (2014) evaluated semi-purified mixed glycerin (soy oil + animal fat) levels of up to $16 \%$ and did not observe effects on the carcass characteristics. Similar findings were also reported by Hanczakowska et al. (2010), who evaluated crude and semi-purified glycerin.

Table 4 - Carcass and meat characteristics of pigs fed diets with different glycerin levels in the finishing stage

\begin{tabular}{|c|c|c|c|c|c|c|c|c|}
\hline & \multicolumn{4}{|c|}{ Glycerin $(\%)$} & \multicolumn{3}{|c|}{ Significance level* } & \multirow{2}{*}{$\mathrm{CV}(\%)$} \\
\hline & 0 & 5 & 10 & 15 & Linear & Quadratic & Cubic & \\
\hline Hot carcass weight (kg) & 81.67 & 83.54 & 82.66 & 80.83 & 0.9423 & 0.0495 & 0.6434 & 2.31 \\
\hline Backfat thickness (mm) & 13.66 & 15.73 & 14.02 & 14.60 & 0.9845 & 0.3799 & 0.1194 & 12.51 \\
\hline pH45 & 6.33 & 6.32 & 6.30 & 6.35 & 0.8335 & 0.7152 & 0.8154 & 2.65 \\
\hline $\mathrm{pH} 24$ & 5.71 & 5.67 & 5.70 & 5.68 & 0.8748 & 0.7252 & 0.4367 & 1.31 \\
\hline $\mathrm{T} 45\left({ }^{\circ} \mathrm{C}\right)$ & 31.09 & 31.54 & 30.64 & 30.92 & 0.3694 & 0.8602 & 0.2570 & 3.40 \\
\hline$a^{*}$ & 8.62 & 8.14 & 8.89 & 8.18 & 0.5910 & 0.7366 & 0.1002 & 8.91 \\
\hline$b^{*}$ & 0.642 & 0.726 & 0.906 & 0.668 & 0.3969 & 0.4057 & 0.5499 & 56.79 \\
\hline $\mathrm{L}^{*}$ & 49.67 & 48.23 & 47.79 & 49.30 & 0.1541 & 0.0493 & 0.7540 & 3.09 \\
\hline Loin eye area $\left(\mathrm{cm}^{2}\right)$ & 47.86 & 47.90 & 47.31 & 46.04 & 0.5750 & 0.6441 & 0.9952 & 6.48 \\
\hline
\end{tabular}

pH45 - pH measured 45 min after slaughter; pH24 - pH measured 24 h after slaughter; T45 - temperature measured 45 min after slaughter; T24 - temperature measured 24 h after slaughter; $\mathrm{a}^{*}$ - range between green and red; $\mathrm{b}^{*}$ - range between blue and yellow; $\mathrm{L}^{*}$ - range between bright and dull color; CV - coefficient of variation.

Hot carcass: $\mathrm{Y}=78.39+4.292 \mathrm{x}-0.926 \mathrm{x}^{2}\left(\mathrm{R}^{2}=0.05\right)$; dressing percentage: $\mathrm{Y}=69.2295+2.9371 \mathrm{x}-0.6045 \mathrm{x}^{2}\left(\mathrm{R}^{2}=0.16\right)$; and color $\mathrm{L}^{*}: \mathrm{Y}=52.8205-3.8387+0.7365 \mathrm{x}^{2}\left(\mathrm{R}^{2}=0.28\right)$

* Significance level $<0.05$. 


\section{Conclusions}

Glycerin can be used in finishing pig diets without compromising their performance results up to the inclusion level of $15 \%$.

Most of the carcass and meat characteristics of pigs are not changed when animals are fed diets containing up to $15 \%$ glycerin.

Hot carcass weight, carcass yield, and color pattern L* have their highest values when pigs are fed diets with 2.32, 2.43 , and $2.6 \%$ glycerin, respectively.

\section{Acknowledgments}

The authors thank Fundação de Amparo à Pesquisa do Estado de Mato Grosso (FAPEMAT) for the financial support for the research and the fellowship granted to the first author and Fiagril S.A. for donating the glycerin.

\section{References}

ABCS - Associação Brasileira de Criadores de Suínos. 1973. Método brasileiro de classificação de carcaças. ABCS, Estrela.

ANP - Agência Nacional de Petróleo. 2015. Anuário estatístico brasileiro do petróleo, gás natural e biocombustíveis 2015 . Available at: $<$ http://www.anp.gov.br/pg $=76798 \& \mathrm{~m}=\& \mathrm{t} 1=\& \mathrm{t} 2=\&$ $\mathrm{t} 3=\& \mathrm{t} 4=\& \mathrm{ar}=\& \mathrm{ps}=\& 1462910388109>$. Accessed on: Nov. 14, 2015.

Berenchtein, B.; Costa, L. B.; Braz, D. B.; Almeida, V. V.; Tse, M. L. P. and Miyada, V. S. 2010. Utilização de glicerol na dieta de suínos em crescimento e terminação. Revista Brasileira de Zootecnia 39:1491-1496.

Bertechini, A. G. 2006. Nutrição de monogástricos. Editora UFLA, Universidade Federal de Lavras, Lavras.

Brasil. Ministério da Agricultura, Pecuária e Abastecimento. Secretaria de Desenvolvimento Rural. 1995. Normas técnicas de instalações e equipamentos para abate e industrialização de suínos. Portaria n. 711, de 1 novembro de 1995. Diário Oficial da União, Brasília, DF, Brasil. p.1-100.

Brasil. Ministério da Agricultura, Pecuária e Abastecimento. 2010. Instrução Normativa $\mathrm{N}^{\circ} 29$. Estabelece os procedimentos para a importação de produtos destinados à alimentação animal e a uso veterinário. Available at: <http://sistemasweb.agricultura.gov.br/ sislegis/action/detalhaAto.do?method=visualizarAtoPortalMapa $\&$ chave $=419570576>$. Accessed on: July 31, 2015.

Brêtas, A. A.; Ferreira, R. A.; Amarante Júnior, V. S.; Pereira, W. E.; Fonseca, J. B. and Caldas, F. R. L. 2011. Balanço eletrolítico para suínos machos castrados em crescimento mantidos em ambiente de alta temperatura. Ciência e Agrotecnologia 35:186-194.

Cerrate, S.; Yan, F.; Wang, Z.; Coto, C.; Sacakli, P. and Waldroup, P. W. 2006. Evalution of glicerine from biodiesel production as a feed ingredient for broilers. International Journal of Poultry Science 5:1001-1007.

Della Casa, G.; Bochicchio, D.; Faeti, V.; Marchetto, G.; Poletti, E.; Rossi, A.; Garavaldi, A.; Panciroli, A. and Brogna, N. 2009. Use of pure glycerol in fattening heavy pigs. Meat Science 81:238-244.

Dozier, W. A.; Kerr, B. J. and Branton, S. L. 2011. Apparent metabolizable energy of crude glycerin originating from different sources in broiler chickens. Poultry Science 90:2528-2534.
Edwards, L. N.; Engle, T. E.; Paradis, M. A.; Correa, J. A. and Anderson, D. B. 2010. Persistence of blood changes associated with alteration of the dietary electrolyte balance in commercial pigs after feed withdrawal, transportation, and lairage, and the effects on performance and carcass quality. Journal of Animal Science 88:4068-4077.

Egea M.; Linares, M. B.; Garrido, M. D.; Madrid, J. and Hernández, F. 2016. Feeding Iberian $\times$ Duroc cross pigs with crude glycerine: Effects of diet and gender on carcass and meat quality. Meat Science 111:78-84.

Gallego, A. G.; Moreira, I.; Pozza, P. C.; Carvalho, P. L. O.; Sierra, L. M. P. and Costa Filho, C. L. 2014. Neutral semi-purified glycerin in starting pigs feeding glicerina semipurificada neutralizada na alimentação de leitões. Semina: Ciências Agrárias 35:2831-2842.

Gonçalves, L. M. P.; Moreira, I.; Pozza, P. C.; Carvalho, P. L. O.; Toledo, J. B. and Penuelasierra, L. M. 2014. Semi purified glycerins in growing and finishing pigs feeding (30-90 kg). Revista Brasileira de Saúde e Produção Animal 15:221-226.

Gomide, A. P. C.; Brustolini, P. C.; Ferreira, A. S.; Paulino, P. V. R.; Lima, A. L.; Scottá, B. A.; Rodrigues, V. V.; Camara, L. R. A.; Moita, A. M. S.; Oliveira Junior, G. M.; Ferreira, R. C. and Formigoni, A. S. 2012. Substituição de milho por glicerina bruta em dietas para suínos em terminação. Arquivo Brasileiro de Medicina Veterinária e Zootecnia 64:1309-1316.

Hanczakowska, E.; Weglarzy, K.; Beata Szymczyk, B. and Hanczakowski, P. 2010. Effect of adding crude or refined glycerol to pig diets on fattening performance, nutrient digestibility and carcass evaluation. Annals of Animal Science 10:67-73.

Honikel, K. O. 1998. Reference methods for the assessment of physical characteristics of meat. Meat Science 49:447-457.

Huepa, L. M. D.; Moreira, I.; Pozza, P. C.; Carvalho, P. L. O.; Pasquetti, T. J. and Sierra, L. M. P. 2015. Neutralized semi-purified in prestarting piglet feeding (6 to $15 \mathrm{~kg}$ ). Semina: Ciências Agrárias $36: 2839-2848$

Kerr, B. J.; Weber, T. E.; Dozier, W. A. and Kidd, M. T. 2009. Digestible and metabolizable energy content of crude glycerin originating from different sources in nursery pigs. Journal of Animal Science 87:4042-4049.

Lin, E. C. C. 1977. Glycerol utilization and its regulation in mammals. Annual Review Biochemistry 46:765-795.

Linares, M. B.; Teruel, M. R.; Egea, M.; Villodre, C. M.; HernándezRuipérez, F.; Madrid, J. and Garrido, M. D. 2014. Fat, meat quality and sensory attributes of LargeWhite $\times$ Landrace barrows fed with crude glycerine. Spanish Journal of Agricultural Research 12:717-726.

Melo, D. S.; Faria, P. B.; Cantarelli, V. S.; Rocha, M. F. M.; Pinto, A. M. B. F. and Ramos, E. M. 2014. Qualidade de carne de suínos com o uso de glicerina na alimentação. Arquivo Brasileiro de Medicina Veterinária e Zootecnia 66:583-592.

Mendoza, O. F.; Ellis, M.; Mckeith, F. K. and Gaines, A. M. 2010 Metabolizable energy content of refined glycerin and its effects on growth performance, and carcass and pork quality characteristics of finishing pigs. Journal of Animal Science 88:3887-3895.

Mourot, J.; Aumaitre, A.; Mounier, A. ; Peinaiu, P. and Francois, A. D. 1994. Nutritional and physiological effects of dietary glycerol in the growing pig. Consequences on fatty tissues and post morten muscular parameters. Livestock Production Science $38: 237-244$.

Oliveira, J. S.; Antoniassi, R.; Freitas, S. C. and Muller, M. D. 2013. Composição química da glicerina produzida por usinas de biodiesel no Brasil e potencial de uso na alimentação. Ciência Rural 43:509-512.

Oliveira, L.; Madrid, J.; Ramis, G.; Martínez, S.; Orengo, J.; Villodre, C.; Valera, L.; López, M. J.; Pallarés, F. P.; Quereda, J. J.; Mendonça, L. and Hernández, F. 2014. Adding crude glycerin to nursery pig 
diet: effect on nutrient digestibility, metabolic status, intestinal morphology and intestinal cytokine expression. Livestock Science 167:227-235.

Rostagno, H. S.; Albino, L. F. T.; Donzele, J. L.; Gomes, P. C.; Oliveira, R. F.; Lopes, D. C.; Ferreira, A. S.; Barreto, L. S. T. and Euclides, R. F. 2011. Tabelas brasileiras para aves e suínos: composição de alimentos e exigências nutricionais. 3.ed. Universidade Federal de Viçosa, Viçosa, MG, Brazil.

Santos, L. S.; Caldara, F. R.; Santos, R. K. S.; Naas, I. A.; Foppa, L.; Garcia, R. G. and Paz, I. C. L. A. 2014. Comparison of methodologies for assessment of pork loin eye área. Boletim de Indústria Animal 71:211-216.
Schieck, G. C.; Shurson, B. J.; Kerr, B. J. and Johnston, L. J. 2010. Evaluation of glycerol, a biodiesel co-product, in grow-finish pig diets to support growth and pork quality. Journal of Animal Science 88:3927-3935.

Verussa, G. H. 2015. Valor nutricional da glicerina determinado com diferentes metodologias sobre o desempenho e parâmetros séricos em suínos. Dissertação (M.Sc.). Universidade Federal de Mato Grosso, Sinop, MT, Brazil.

Verussa, G. H.; Corassa, A.; Pina, D. S.; Ton, A. P. S.; Komiyama, C. M. and Teixeira, A. O. 2017. Performance and sérum parameters of growing pigs fed diets containing semi-purified glycerin. Revista Colombiana de Ciencias Pecuarias 30:11-20. 